\title{
FUNGSI SENI LUKIS BALI MODERN ANAK AGUNG GEDE SOBRAT
}

\author{
A.A Gede Yugus \\ Jurusan Seni Rupa Murni, Fakultas Seni Rupa dan Desain, \\ Institut Seni Indonesia Denpasar, Indonesia
}

\begin{abstract}
This article examines the important of appreciating the paintings of A.A. Gede Sobrat, due to the interesting form, theme, and function of the painting. The work of this painter has its distinctive characteristic that is well known and has enhanced the artistic level of Bali and Indonesia in painting. Anak Agung Gede Sobrat obtained inspiration from Walter Spies and R. Bonnet, although Sobrat previously focused on Balinese traditional painting. His encounter with Walter Spies and R. Bonnet provides artistic ideas in painting arts. The author wishes to understand the form, function, and meaning of the artistic exploration of Anak Agung Gede Sobrat.
\end{abstract}

Key words: lukisan, and Anak Agung Gede Sobrat.

Seni lukis Bali berkembang tumbuh sejalan dengan tata nilai dan budaya kehidupan masyarakat Bali. Realitas keberadaannya tampak sejak masuknya agama Hindu-Budha yang mempengaruhi budaya di Bali pada abad X, pada saat Bali diperintah oleh kerajaan-kerajaan kecil. Ragam budaya Bali prapenjajahan merupakan pembauran antara unsur pribumi lokal dengan aneka unsur indo-Jawa, masuk menyusul invansi budaya Majapahit tahun 1343. Seni lukis pada waktu itu didominasi oleh bentuk " wayang ", yaitu bentuk gambar-gambar ilustrasi naratif, baik sebagai ceritera maupun ikonografinya yang diturunkan langsung dari kesenian wayang. Peminatnya adalah kaum bangsawan yang berfungsi untuk menghias puri-puri mereka dan bagi masyarakat biasa difungsikan untuk kebutuhan menghias pura. Juru gambar, pelukis, atau pematung. Yang disebut dengan istilah "seniman", pada waktu itu, belum dikenal mereka pada umumnya berkarya yakni merupakan bagian dari tugas sosial dan religiusnya yang bersifat ngayah. Hampir semua karya seni memiliki fungsi religius, yaitu berorientasi keagamaan yang sangat menentukan wujud atau mau pun penggunaan karya yang bersangkutan (Couteu, 2002:109). 
Saat berkarya seni, seniman tidak dapat berkarya tanpa mulai mempertimbangkan "dewasa" positif dan negatif. Nilai spiritual yang bersifat relegius magis, seperti gambar rerajahan, gambar bbcggsimbolsimbol pretima, merupakan gambar yang sangat disucikan, sehingga baru bisa dikeluarkan pada waktu-waktu tertentu, seperti pada odalan dan harihari suci lainnya. Namun karya seni lukis dijumpai pada bangunan suci yang difungsikan sebagai penghias pada upacra keagamaan, yakni untuk hiasan dinding, hiasan pada ider-ider, kober, langse, umbul-umbul, atau lelontek. Dalam hal ini umumnya karya-karya lukisan selalu mengambil tema dari mitologi seperti ceritera Mahabrata dan Ramayana yang bersumber dari buku-buku ajaran agama Hindu. Akan tetapi bentuk lukisan rerajahan yang digambarkan di atas kain putih berupa perpaduan aksara suci yang berujud Ong Kara (simbol Tuhan ). Sebelum memulai melukis para seniman mesti melakukan doa agar apa yang digoreskan mendapat kesucian dan mewujudkan sepirit (Arsana, 2004:205).

Dalam perkembangan berikutnnya seni lukis Bali juga tidak menutup diri dari pengaruh-pengaruh Barat. Pengaruh ini sudah ada sebelum pemerintah kolonial Belanda berkehendak menguasai penuh Pulau Bali awal abad XX. Hal ini terbukti dengan adanya patra jahe, patra punggel, patra cina, dan patra olanda dalam pembendaharaan dalam seni lukis di Bali, atau pada patra awangga, campuran gaya ukiran Bali, Belanda, dan Tiongkok (Darmawan, 2006:22).

Invasi Belanda di Pulau Bali, pada tahun 1845-1848 di Bali utara dan tahun 1905-1908 di Bali selatan, telah menghancurkan seluruh landasan sosial politik seni rupa prakolonial Bali. Hal ini dimulai dengan kerajaankerajaan lama yang ada pada waktu itu diintegrasikan di dalam administrasi kolonial; yakni salah satu pilar budaya Bali dan pemesan utama karya seni menghilang begitu saja. Tatanan ekonomi dirombak, penaklukan Bali oleh Belanda berdampak langsung dan terasa pada berbagai seni rupa. "Pasaran" baru tumbuh terbuka, produksi barang-barang bertambah secara drastis melampaui permintaan. Di samping itu terjadi perubahan pasar. Oleh karena pasaran tidak lagi membutuhkan simbol-simbol agama, sehingga tema-tema karya seni langsung berubah. Selain itu, adanya pembaharuan pengguna material baru, yaitu bahan dan alat baru mulai beredar, stilistik dan proses berkarya dipercepat.

Tahun 1920-an dibuka kantor pariwisata di Singaraja. Karya ukiranukiran sejak tahun itu mulai diproduksi dalam volume yang semakin meningkat dan wisatawan yang berkunjung semakin meningkat. Muncul pemilahan yang jelas antara pungsi yang bersifat relegius lama juru gambar yang masih bertahan dengan fungsi komersial sekuler yang baru berkembang. Selain istilah juru gambar, muncul, istilah "seniman lukis". Tema karya-karyanya masih terangkat dari unsur-unsur kesenian lama, seperti relief, ceritera Tantri, dan fabel. 
Akhir dasawarsa 1920-an, intervensi langsung dari seniman Barat, yang memberikan corak tersendiri pada perkembangan seni lukis Bali. Perkembangan itu lazimnya disebut gerakan Pita Maha pada tahun 1935 atau seni lukis Bali Modern. Intervensi ini pertama melahirkan mitos Bali sebagai "pulau sorga" yang kemudian melanda dunia Barat pada abad 20-an, lebihlebih diketahui setelah beredarnya foto-foto wanita Bali sedang mandi. Pengangkatan istilah Bali sebagai surga ini merupakan kelanjutan dari dampak tren yang dimulai oleh pelukis Gauguin pada akhir abad XIX, yaitu di Laut Fasifik "Hawai" ketika dia meninggalkan Perancis dan melanjutkan perjalanan ke Bali, entah menjadi petualang, sebagai, cendekiawan, atau seniman (Ibid, $p: 108)$. Dalam hal ini di antaranya terdapat figur Walter Spies (1895-1942) dan Rudolf Bonnet (1895-1978), keduanya berperan menentukan dalam evolusi seni lukis di Bali.

Selanjutnya, terjadi perkembangan mendapat pengaruh seniman asing tersebut (Anonim,1978). Di samping itu, kedua seniman ini banyak membawa pengaruh dan perubahan pada bidang seni lukis di Bali. Selain itu, terjadi perpaduan budaya antara pelukis Bali yang telah memiliki keterampilan teknik tradisional yang tinggi dengan pelukis asing ata Barat (R. Bonnet dan Walter Spies ) yang menguasai teknik baru dari Barat.

Akibat perpaduan budaya tersebut menyebabkan seniman-seniman muda Bali membuka diri, terutama perkembangannya sikap toleransi terhadap konsep-konsep baru yang dinilai positif untuk meningkatkan wawasan, pengetahuan seni, dan yang lainnya. Kontak budaya ini terus berlangsung sehingga terbentuklah perkumpulan pelukis yang di beri nama Pitha Maha tahun 1935. Kedua pelukis Barat tersebut, bersama-sama seniman lokal di Ubud, terus mengadakan pembaharuan, khususnya di bidang seni lukis. Di samping itu Walter Spies dan R.Bonnet memberi pendidikan kepada mereka yang belajar melukis dan tertarik terhadap realis, yakni dengan mempelajari proporsi dan anatomi, kemudian diolah menjadi corak tradisional yang bersifat dekoratif. Munculnya R. Bonnet dan Walter Spies di tengah-tengah pelukis-pelukis Pita Maha melahirkan corak dan identitas terhadap para seniman masing-masing. Hal ini tentunya menimbulkan perbedaan dengan seni lukis yang berkembang sebelumnya. Dalam hal ini seperti penciptaan seni lukis untuk kepentingan relegius atau keagamaan yang di kerjakan secara komunal, yaitu masyarakat secara bersama-sama mengerjakan, kemudian pada hasil akhir tidak perlu mencamtumkan identitas penciptanya.

Dari perubahan pola tersebut, muncullah seniman yang kreatif menonjolkan identitas karyanya, di antaranya di Ubud yang sangat menonjol adalah pelukis A.A. Gede Sobrat, A.A Gede Meregeg, Ida Bagus Made, I Gusti Nyoman Moleh, I Dewa Ketut Ding, dan puluhan seniman lukis lainnya. Termasuk di Br. Padang Tegal. Di Pengosekan muncul pelukis I Gusti Ketut Kobot, I Gusti Baret, I Ngendon dan yang lainya. Seni lukis 
Bali modern yang baru tumbuh ini mendapat sentuhan modern dari seni lukis corak Barat sehingga melahirkan berbagai gaya atau stil lukisan dengan ciri khas masing-masing. Sentuhan budaya Barat ini mempercepat proses pematangan dan menumbuhkan barbagai stil seperti lukisan gaya Ubud, Batuan, Pengosekan, Tebesaya, Kutuh, Padang Tegal, dan lain-lainnya. Dari berbagai perubahan dan pembaharuan yang dibawa pelukis Barat tersebut, kemudian muncul tema-tema kehidupan sehari-hari, di samping itu, ciri khas yang kedua adalah munculnya garis anatomi, perspektif, pengertian komposisi, proporsi, sinar bayangan, dan teknik seni lukis yang lebih disempurnakan.

Salah seorang pelukis Bali yang menonjol saat itu adalah pelukis A.A. Gede Sobrat dari Banjar Padang Tegal Ubud. A.A. Gede Sobrat sebagai pelopor pembaharuan seni lukis Ubud. Bakat seni dari garis ayah dan juga dari garis ibu. Bakat seni dari garis ibu menurun dari kakeknya bernama I Seleseh, adalah seorang undagi terkemuka di desanya dalam mengerjakan Puri Ubud, dan dari ibu yang sangat menguasai jejaitan banten. A.A. Gede Sobrat dilahirkan di Banjar Padang Tegal Ubud, Kabupaten Gianyar. Bakat seninya telah tampak sejak kecil. Dia selalu senang menonton berbagai pertunjukan kesenian, khususnya pertunjukan wayang kulit, yaitu bentuk kesenian yang memiliki nilai pendidikan, etika, dan kesenirupaan. Pada usia belasan tahun, yakni untuk membantu kebutuhan ekonomi keluarga, A.A. Gede Sobrat telah bekerja sebagai penerima telepon di Puri Ubud, yang saat itu sudah sering menerima kunjungan wisatawan domestik dari mancanegara. Di sinilah awal perkenalan dengan wisatawan, termasuk R.Bonnet dan Walter Spies, yang saat itu sebagai tamu Puri Ubud. Dengan perantara Cokorda Agung Sukawati persahabatan Sobrat dengan tamunya semakin akrab.

Dari perkenalan dan keakrabannya dengan kedua pelukis Barat tersebut, memperkuat keinginan A.A. Gede Sobrat belajar melukis pada kedua seniman Barat itu. Berbekal pengalaman seni ornamen dan seni lukis wayang, yang diperoleh dari kakeknya pada waktu dia masih kecil, dan dengan memanfaatkan bakat dan kemauan yang dimiliki, maka mulailah Sobrat belajar melukis bersama A.A. Gede Meregeg. Dalam hal ini Walter Spies dan R. Bonet memberikan teori-teori dan teknik baru tentang seni lukis Barat kepada A.A. Gede Sobrat, kemudian ditekuni dan dapat dikuasai dengan cepat, baik teknik, pewarnaan, ide, maupun pemakaian bahan modern lainnya. Di sela-sela kesibukan melukis, A.A. Gede Sobrat sangat aktif di masyarakat dalam berbagai kegiatan ritual seperti ngodi (dekorasi pada peralatan pembuatan upacara ngaben), maupun menghias purapura/pemarajan. Selain itu aktip pula membimbing rekan-rekannya serta anak-anak dalam bidang mewujudkan konsep, komposisi, dan pewarnaan seni lukis. Pada tahun 1950-an oleh Raja Yogya dan Solo ia diminta ikut menghias keraton. Selain itu sebagai pendidik formal seni rupa, yaitu pada 
tahun 1957 diminta menjadi dosen luar biasa di ASRI Yogyakarta yang dipimpin oleh Bapak Katamsi dalam mata kuliah seni lukis.

Seni lukis telah tumbuh dan berkembang dengan subur jika didukung oleh lingkungan. Dalam hal ini lingkungan ada dua jenis, yakni lingkungan dalam yang dikenal dengan internal, yaitu kemampuan wawasan serta konsep-konsep yang dimiliki oleh senimannya, selanjutnya lingkungan luar yang dikenal sebagai lingkungan eksternal, yaitu pengaruh fisik lingkungan yang berkembang di sekitar seniman. seni lukis dalam lingkungan eksternal tidak terlepas dari segi-segi kehidupan masyarakat seni lukis, seperti hasil seni rupa yang dibatasi oleh bentuk ukuran dua atau tiga dimensional, yang bertujuan untuk menciptakan kembali atau hayalan visual ke atas bidang datar, dengan unsur garis-garis, bidang, dan warna. Pengungkapan ruang dapat dinyatakan secara semu, baik melalui penggambaran perspektif garis maupun warna (Sudarmo, dan Wiyadi, 1983:4).

Sebagai suatu kajian budaya, tulisan yang berjudul Seni Lukis Bali Modern Anak Agung Gede Sobrat akan menyoroti tentang bentuk dan fungsi yang terkandung di dalamnya.

\section{PERKEMBANGAN SENI LUKIS A.A. GEDE SOBRAT}

Di Bali, A.A. Gede Sobrat adalah seorang pelopor, terutama dalam perkembangan seni lukis Bali Modern. Dalam bukunya, Suwaji dkk. (1981), menyatakan bahwa A.A. Gede Sobrat adalah tokoh penting dalam perkembangan seni lukis di Bali. Hal ini diketahui karena A.A. Gede Sobrat dianggap sebagai tonggak kebangkitan seni lukis Bali Baru, pelopor pelukispelukis muda dalam mengembangkan dirinya. Perkembangan seni lukis A.A. Gede Sobrat sudah tampak sejak kecil. Dia mulai gemar menonton pertunjukan kesenian, khususnya pertunjukan wayang kulit, suatu bentuk kesenian yang memiliki nilai-nilai pendidikan dan etika kesenirupaan. Hal ini menumbuhkan minat Sobrat untuk menggambar terutama figur-figur wayang dalam berbagai bentuk dan ceriteranya.

Perkembangan lukisan A.A. Gede Sobrat dapat digolongkan menjadi empat kategori. Pertama pengaruh agama Hindu, dengan tema-tema wayang yang berhubungan dengan upacara keagamaan ditekuni, proses awalnya dia belajar sekitar tahun 1924 sampai kira-kira tahun 1929.

Kedua pengaruh Walter Spies dan tahun 1929 pengaruh R. Bonnet sampai berdirinya Pitha Maha, pengaruh Walter Spies dan R. Bonnet hampir berdekatan datangnya. Kedua seniman asing ini memberikan imbas perkembangan yang sangat penting dalam kehidupan seni seni lukis A.A. Gede Sobrat. Terakhir pengembangan dari pelukis A.A. Gede Sobrat sendiri. Dalam hal ini kebebasan dia sebagai seorang pelukis sampai menemukan jati diri dan kepercayaan dirinya perjalanan proses berkesenian. 
Dalam kategori pertama, merupakan proses awal A.A. Gede Sobrat belajar melukis. Dalam proses ini agama merupakan sumber aneka aspek kehidupan, di samping kehidupan sosial di masyarakat. Kehidupan agama Hindu tidak dapat dipisahkan oleh A.A. Gede Sobrat di dalam aktivitas melukis. Agama Hindu adalah sebagai sumber inspirasi dan motivasi bagi A.A. Gede Sobrat agar dapat menciptakan karya-karya yang secara fisik bernilai estetis dan relegius magis. Sobrat sebagai seorang anggota masyarakat yang patuh terhadap ajaran agama, Sobrat sangat aktif mengabdikan diri dalam berbagai kegiatan yang bertalian dengan pelaksanaan agama, seperti odalan di pura, upacara pitra yadnya, upacara manusa yadnya dan lainya. Dalam kegiatan tersebut A.A. Gede Sobrat tidak menyadari bahwa telah mengalami proses pembelajaran dalam berbagai kegiatan yang dilakukanya bersama di desanya. Di desanya, rumah Sobrat merupakan pusat kesenian hal ini ditunjukkan dengan adanya perkumpulan kesenian arja dan kesenian gambuh. Sudah barang tentu perkumpulan ini memerlukan sarana berupa kostom-kostom, gelung dan gambelan untuk menunjang perlengkapan dalam proses berkesenian. Kebersamaan pada saat itu dirasakan Sobrat dalam aktivitasnya yang senang berkecipung dalam hal menggambar. Pada saat itu, Sobrat dipercayai untuk menggambar dan memberikan ornamen-ornamen pada perlengkapan dalam kegiatan tersebut. Dalam pembelajaran selanjutnya Sobrat makin kelihatan dan dipercayai dalam upacara-upacara keagamaan seperti memberikan ornamen dan penggambaran bentuk wayang untuk dipergunakan dalam sarana upacara seperti lelontek, parbe-parbe, ornamen wanci (tempat meletakkan banten), kajang (sarana upacara ngaben), ornamen-ornamen kori agung dan sarana lainnya. Karena kepercayaan dalam beragama yang tulus, maka dalam kebersamaan tersebut Sobrat berusaha bekerja dengan sungguhsungguh dengan mengharapkan hasil karya yang sebaik-baiknya dan mendapat kepuasan dalam kegiatannya, tanpa ingin menuangkan emosi dalam pekerjaan,. sehingga pada saat itu tidak berkeinginan untuk membubuhi nama pada hasil karyanya. Dalam hal ini lebih memandang pekerjaan semacam itu sebagai suatu pengabdian kepada kepentingan masyarakat sehingga karya-karya Sobrat pada saat itu tidak berisi nama.

Walter Spies pertama kali datang ke Bali tahun 1924. Dalam hal ini gambar-gambar orang Bali yang ditemukan oleh Walter Spies, masih bergaya klasik tradisional. Mutu estetik yang terpancar dari lukisan-lukisan itu sangat memukau pelukis Barat. Dalam puluhan surat-surat yang ia kirim kepada ibunya di Jerman, ia tidak henti-hentinya memuji dan mencetuskan rasa kagumnya terhadap mutu seni yang telah dicapai oleh para pelukis Bali, khususnya di Ubud dan Kamasan. Sebenarnya bukan Walter Spies yang pertama merasakan rasa kagum atas keindahan gambar dan lukisan Bali. Oleh karena tahun 1910 seorang pelukis berkembangsaan Belanda, W.O. J. Nieuwenkamp, telah menerbitkan buku yang sangat berkesan di negerinya, 
dan membuka mata tentang seni gambar di Bali. Walaupun Walter Spies orang yang pertama kali menganjurkan kepada pelukis Bali agar menggambar obyek kehidupan sehari-hari, tetapi pelukis Bali sudah melakukan hal itu secara tidak sengaja, dan spontan. Gaya semacam ini tampak pada lukisan karya pelukis ternama di Ubud Gusti Nyoman Lempad, setelah anjuran Walter Spies pada tahun 1929 (Djelantik, 1988:30).

Walter Spies datang ke Bali sekitar 1895-1942 adalah seniman berkebangsaan Jerman yang lahir di Mosko. Dalam hidupnya ia dikenal sebagai ahli musik dan pandai bemain piano, tetapi bakat melukisnya juga tak kalah hebatnya. Di samping main musik ia juga melukis. Ia datang ke Indonesia karena tertarik dengan keindahan Pulau Bali. Ia terpesona melihat keindahan alam Bali. Kehidupan masyarakatnya yang agraris dan relegius membuat W. Spies tertarik untuk tinggal di Bali dan jatuh cinta kepada Bali. Pada tahun 1927 Walter Spies datang ke Bali ( Gung Man, Bali Post, Ngurah Ty., 2006:77).

Kedatangan Walter Spies ke Bali kemudian menetap di Ubud. Hal ini menyebabkan terjadi kontak budaya antara pelukis Bali yang telah memiliki teknik tradisional yang tinggi dengan pelukis asing tersebut. A.A. Gede Sobrat yang pada saat itu bekerja sebagai pegawai telepon di Ubud, diperkenalkan oleh Cokorda Agung Sukawati dari Puri Ubud dengan pelukis Walter Spies. Mungkin Sobrat dianggap mempunyai bakat yang menonjol dalam bidang melukis oleh Cokorda Agung Sukawati. Walter Spies yang tinggal di Campuan pada saat itu sering dilihat oleh Sobrat ketika melukis. Karena ketertarikan Sobrat untuk melukis, maka sehabis bekerja (sebagai penjaga telepon) ia datang ke studio Walter Spies untuk melihat Spies melukis. Oleh karena seringnya Sobrat melihat Walter Spies melukis, maka muncullah keinginan untuk A.A. Gede Sobrat untuk mengembangkan wawasan melukis yang sudah ditekuni sebelumnya. Mulai saat itu tumbuh keinginan untuk memdalaminya, sehingga Sobrat seringsering mengunjungi Walter Spies saat melukis. Pada saat itu Walter Spies sedang melukis di studionya, Sobrat datang melihat Walter Spies melukis. Saat itu, "kening" Sobrat dicolek dengan kuas oleh Walter Spies, kemudian Walter Spies bertanya kepada Sobrat, "Kamu mau belajar melukis? Pada saat itu Sobrat mengatakan mau dengan sangat antusias oleh karena kegembiran, besok paginya Sobrat langsung belajar melukis di Studio Water Spies yang bertempat di Campuan Ubud (Wawancara A.A.Anom Sobrat Juli, 2006, di rumahnya).

Sobrat mulai belajar melukis dengan bekal seni lukis wayang yang dimiliki, ia berguru kepada Walter Spies. Dari permulaan Sobrat belajar melukis pada Walter Spies setiap datang dari menjaga telepon, Sobrat terus datang ke studio Walter Spies, dan langsung belajar melukis. Pada awal Sobrat belajar melukis, disuruh membuat hiasan pada kotak-kotak untuk 
peralatan kebutuhan Walter Spies, seperti: tempat obat, pintu rumah, jendela-jendelanya, dengan hiasan, seperti: gambar binatang, manusia, flora dan fauna. Hal ini yang menyebabkan A.A.Gede Sobrat mempunyai teknik dasar, teknik mewarna dan menghias. Namun, sebelunnya A.A. Gede Sobrat hanya mengetahui teknik menghias alat-alat upacara keagamaan, seperti: wanci, alat tempat gebogan yang ditaruh di pemerajan, dan tempat suci, yaitu parbe, langse, lelontek dan yang lainya. Selanjutnya di studio Walter Spies, ia terus dibimbing baik melalui material kertas maupun kanvas. Ia diberikan kebebasan oleh Walter Spies untuk melukis apa yang diinginkan. Dari proses pembelajaran ini muncullah pemikiran baru dan wawasan baru pelukis A.A. Gede Sobrat sehingga ia mengetahui teknik penyinaran, gradasi warna, teknik warna, perspektif, dan menguasai peralatan-peralatan baru, yang diperkenalkan oleh Walter Spies. Dalam tahapan ini terlihat kejelian serta kepekaan dalam menangkap objek, Sobrat terus berkembang dan A.A. Gede Sobrat semakin bersemangat belajar di studio Walter Spies. Dalam proses selanjutnya, apa yang diberikan Walter Spies cepat ditangkap oleh Sobrat, sehingga hasil didikan Walter Spies sangat membanggakan.

\section{FUNGSI SENI LUKIS A.A. GEDE SOBRAT}

Menurut Bastomi (1992:50), fungsi seni pada umumnya dapat dibedakan atas seni sakral, yaitu seni yng berfungsi untuk kepentingan halhal yang berhubungan dengan agama dan kepercayaan. Seni yang lahir untuk kepentingan agama bernilai tinggi sebab terciptanya seni tersebut atas dasar rasa pengabdian kepada yang dipujanya. Selanjutnya, seni sekuler adalah seni yang berfungsi untuk hal-hal yang berhubungan dengan kebutuhan duniawi. Dalam hal ini seni sebagai alat atau objek. Oleh karena itu, maka muncullah berbagai fungsi seni, yaitu seni untuk perdagangan, penerangan, komunikasi, pendidikan, apresiasi, rekreasi, dan terapi.

\section{Fungsi Estetis}

Manusia sebagai makhluk sosial memiliki hasrat untuk menciptakan karya seni. Seni sebagai ekspresi merupakan hasil ungkapan batin seorang seniman yang tertuang ke dalam karya seni lewat medium dan alat. Medium merupakan sarana yang dipergunakan untuk menunjang terbentuknya sebuah karya seni. Karya seni yang biasa diciptakan erat kaitannya dengan keindahan atau estetis.

Keindahan dalam arti luas merupakan pengertian bangsa Yunani, yang di dalamnya tercakup pula ide atu kebaikan. Plato misalnya menyebut tentang watak yang indah dan hukum yang indah, sedangkan Aristoteles merumuskan keindahan sebagai sesuatu selain baik juga menyenangkan. Dalam hal ini keindahan dalam arti estetika, menyangkut pengalaman estetis 
seseorang dalam hubungannya demgam segala sesuatu yang diserapnya. Namun, keindahan dalam arti yang terbatas hanya menyangkut bendabenda berupa keindahan bentuk dan warna (Kartika, 2004:10-11).

Herbert Read dalam The Meaning of Art merumuskan bahwa keindahan adalah kesatuan dari hubungan bentuk yang terdapat di antara pencerapan-pencerapan indrawi kita. Di sisi lain Djelantik (1990:14) mengatakan bahwa semua benda atau kesenian mengandung tiga aspek, yakni wujud, bobot atau isi, dan penampilan.

Berdasarkan uraian di atas yang dimaksud dengan fungsi adalah sesuatu yang berkaitan dengan guna dan maanfaat yang tidak berdiri sendiri, tetapi menerangkan kaitan korelasi antara satu hal dengan hal yang lain dalam satu sistem yang terintegrasi. Jadi, etika lukisan A.A. Gede Sobrat dapat dilihat melalui wujud lukisan yang diciptakan berdasarkan unsur-unsur yang terkandung dalam seni lukis, seperti: garis, bentuk, warna, tekstur, dan gelap terang di dalam media kanvas. Unsur-unsur lukisan A.A. Gede Sobrat tersebut tersusun berdasarkan struktur penyusunan, seperti: komposisi, proporsi, irama, balance, kontras, pusat pandang, kesungguhan, harmoni, dan unity.

Seni lukis A.A. Gede Sobrat, dilihat dari wujud yang ditampilkan, dan nilai-nilai estetikanya merupakan pembaharuan sehingga memberikan nafas baru dalam perkembangan seni lukis Bali Modern. Berbagai wujud karya dan tema-tema yang ditampilkan. A.A. Gede Sobrat mendapat sentuhan Walter Spies dan R. Bonnet. Walaupun demikian Sobrat tetap mempunyai identitas dan dapat mengembangkan kepribadiannya sehingga bebas dari pengaruh Walter Spies dan R. Bonnet. Kondisi dan kreativitas ini dapat dilihat dari karya-karya yang mengandung nilai-nilai estetis, seperti objekobjek yang ditampilkan dengan kekuatan stilisasi antarmanusia dengan bentuk wayang. Dari sudut tema terjadi perubahan, yaitu karya seni rupa tidak lagi memiliki fungsi religius Ciri-ciri lainnya penggambaran objek lukisan selalu berupa suatu kejadian atau peristiwa-peristiwa keseharian yang menarik perhatian, misalnya, suasana pasar, suasana upacara agama, kehidupan sehari-hari, episode ceritera pewayangan, dan lain-lain (Murdana, 2001:113). Tema-tema tersebut di atas merupakan rekaman peristiwa yang dapat menuturkan kegiatan orang Bali dalam kesehariannya. Pemilihan objek-objek tersebut telah terkontrol dan terseleksi kemudian tertuang ke dalam media kanvas. Kontrol dan seleksi tersebut, baik berupa objek yang akan digambar, besarnya kanvas yang dipakai, maupun unsur di atas media.

Garis merupakan faktor yang sangat dominan dalam pengungkapan estetis seni lukis A.A. Gede Sobrat. Garis dieksploitasi sebagai kontur, pengungkapan bentuk yang kuat sehingga berhasil mengemukakan karakter objek yang ditampilkannya secara realis. Garis dalam pengungkapan bentuk yang kuat dibuat sebagai kontur atau nyawi yang dibuat merata ke seluruh objek lukisan. Sobrat yang matang dalam penguasaan teknis dengan teknik 
pewarnaan hitam putih untuk mendapatkan kesan gelap-terang dalam karyakarya yang ditampilkannya. Penerapan warna secara transparan dan berulang-ulang pada objek yang dibuat secara merata dan bervariasi, kemudian berakhir dengan pemasangan warna putih secara gradasi nyenter yakni dengan tujuan memperjelas gelap terang dan memberi kesan penonjolan pada lukisannya sehingga menghasilkan perspektif warna dan irama yang diinginkan dengan warna-warna realis.

Di samping itu, selain memiliki unsur-unsur seperti: warna, garis, dan unsur lainnya, lukisan A.A. Gede Sobrat juga memiliki keindahan dalam bentuk ide yang diungkapkannya. Cakupan aspek ide adalah filosofi, kejiwaan, serta respon terhadap ruang dan waktu. Maksudnya dalam mencipta seni A.A. Gede Sobrat tidak secara sembarangan, tetapi menggunakan filosofi, yaitu filosofi seni.

Lebih lanjut, ide adalah modal pokok bagi pengembangan kreativitas seni lukis sehingga melahirkan sesuatu yang baru berbeda dengan hasil karya lainnya. Kemampuan seorang seniman dalam melahirkan gagasannya menentukan keberhasilannya dalam berekspresi, yakni dengan memilih tampilan objek karya yang memberikan pengalaman estetik yang menyenangkan.

Demikian pula tanggapan terhadap pelukis A.A. Gede Sobrat, sebelum berkarya idenya tumbuh dari pengamatan alam yang ada di sekitarnya. baik melalui kegiatan-kegiatan yang dilakukannya maupun dari pengamatan objek di lingkungannya. selanjutnya Filsuf Arthur Schopenhauver (dalam Gie, 2004:23) menyatakan bahwa seni adalah suatu bentuk pemahaman terhadap kenyataan. Dalam hal ini inti dari kenyataan yang sejati adalah kemauan yang bersifat semesta, sedangkan kenyataan duniawi berupa ideide hanyalah wujud luar dari kemauan semesta itu. Ide itu bersifat abadi dan tak berubah. Ide-ide ini menampakkan diri atau mempunyai perwujudan dalam benda-benda khusus. Ide adalah angan-angan, harapan dalam pikiran yang nantinya menjadi petunjuk dalam mewujudkan karya seni. Karya seni yang sering kita lihat, baik lukisan maupun yang lainnya merupakan tiruan dari ide yang telah tumbuh sebelumnya. Ide sangat penting untuk dapat kita renungkan dalam berkarya seni.

Ide A.A. Gede Sobrat dalam melukis, yakni tentang sebagai wujud rasa cinta terhadap kehidupan masyarakat Bali. Tema-tema lukisan A.A. Gede Sobrat berkisar di antara kehidupan sehari-hari, seperti: suasana pasar, suasana pertunjukan tari-tarian, suasan di perkampungan, dan figur-figur manusia, seperti gadis Bali. Dari sekian tema ini yang paling mendominasi adalah kegiatan yang dilakukan orang di pasar, seperti: orang berbelanja, menjual , tawar-menawar dan lain-lain. Dalam tema ini motif digambarkan secara realis-dekoratif dengan menunjukkan proporsi dan anatomi plastis yang disederhanakan dan digayakan agar terhindar dari kesan kaku dan dipaksakan. Seleksi dan kontrol tersebut berupa objek yang akan dilukis 
serta material yang dipergunakan dalam penyusunan unsur seni di atas media kanvas. Pertama, Sobrat dalam mendapatkan hasil karya yang mengandung nilai estetis,yakni dengan mengumpulkan fakta-fakta, data dan sensasisensasi yang digunakan oleh alam pikiran sebagai bahan mentah untuk mendapatkan ide-ide baru. Objek-objek yang akan dilukisnya dibuatkan seket-seket atau bentuk-bentuk dan penghayatan yang mendalam di samping mengadakan eksperimen terhadap objek yang akan dibuat. Proporsi objek dengan kanvas serta momen yang akan diungkapkan telah melalui kontrol dalam ide, yang nantinya akan dituangkan ke dalam lukisan. Karya lukis yang merupakan hasil perwujudan ide yang menuntun perwujudan tersebut, kemudian ide yang keluar dari angan-angan tersebut akan terkontrol sehingga menghasilkan karya. Dalam hal ini ide A.A. Gede Sobrat sendiri telah mengandung nilai estetis.

\section{Fungsi Pembaharuan}

A.A.Gede Sobrat adalah salah satu pelukis Bali Modern yang telah membawa perubahan dan pembaharuan dalam bidang seni lukis di Bali. Pembaharuan yang menonjol dilakukan A.A. Gede Sobrat dapat dilihat pada ide, wujud fisik karya yang dituangkan dalam karya lukis, baik berupa teknik dan tema maupun objek lukisannya.

Pembaharuan dalam ide, tema dan teknik dalam berkarya dilakukan A.A. Gede Sobrat. Dalam usaha mewujudkan profesi dan pembentukan pribadinya sebagai seorang pelukis ia beranjak dari bakat yang kemudian dipengaruhi oleh beberapa faktor terkait antara satu dengan yang lainnya, seperti: pendidikan, ilmu pengetahuan, teknologi, dan lingkungan sosial. Faktor-faktor tersebut merupakan paktor-paktor pendukung yang sangat berperan di dalam menjalankan profesi sebagai seorang pelukis. Pada awalnya karya-karyanya A.A.Gede Sobrat dipergunakan sebagai pelengkap upacara. Namun kemudian karya-karyanya mengalami pembaharuan atau perubahan fungsi yang mengarah kepada kebutuhan hidup keluarga. Akan tetapi, yang terpenting dari semua ini adalah ide atau kreativitas seni yang dimiliki. Walter Spies dan R. Bonnet yang memberi pengaruh sangat besar dan masuknya unsur-unsur Barat kepada pelukis A.A. Gede Sobrat. Hal ini menimbulkan perubahan nilai estetika menuju pembaharuan dan perubahan sikap berkesenian. Dari perubahan-perubahan tersebut dihasilkan unsurunsur estetika baru, yakni berupa anatomi, komposisi, perspektif, sinar bayangan, dan teknik.

Pembaharuan juga terjadi dalam bahan. Sebelumnya A.A. Gede Sobrat tidak mengenal alat dan bahan melukis modern seperti: kanvas, cat air, acrilic, dan lain-lain. Setelah mendapat sentuhan pelukis Barat (Walter Spies dan R. Bonnet) barulah mereka mengenal alat dan bahan serta cara lain yang lebih efisien dalam melukis. Namun dalam hal teknik melukis, walaupun secara umum seni lukis Bali Modern tekniknya sama, tetapi A.A. 
Gede Sobrat mempunyai kelebihan yang tidak dimiliki oleh pelukis Bali Modern lainnya. Di samping pembaharuan dalam ide, pengaruh yang bersifat teknis sangat besar peranannya, bahkan ia menyatakan bahwa tahapan melukis yang umum dilakukan untuk mengerjakan seni lukis Bali Modern, yakni dengan urutan seperti: menyeket, mengkontur, (nyawi), dan gradasi hitam putih, di samping warnanya dan penyelesaian dilakukan pula oleh A.A. Gede Sobrat dalam menyelesaikan karyanya. Sentuhan teknik seni lukis Barat dipadukan dengan teknik tradisional yang menjadikan ciri khas teknik seni lukis A.A. Gede Sobrat. Ciri-ciri dan identitas teknis lukisan A.A. Gede Sobrat dapat kita lihat dalam menguasai perspektif, mempelajari kebenaran atau ketepatan dalam mengambil suatu objek dengan menggunakan pertolongan melalui hukum-hukum perspektif praktis yang dapat membantu dalam melukis.

\section{Fungsi Ekonomi}

Sobrat adalah salah satu pelukis yang banyak diburu oleh para kolektor yakni untuk investasi, di samping lukisannya dijadikan sebagai benda komersial yang dapat diperjualbelikan. Populernya lukisan Sobrat sebagai benda koleksi yang bernilai tinggi sehingga para kolektor, baik dari dalam negeri maupun luar negeri ingin mendapatkan atau memiliki lukisan A.A. Gede Sobrat. Para kolektor atau museum biasanya berlomba-lomba untuk mendapatkan karya-karya yang langka, di samping para kolektor merasa koleksinya kurang lengkap jika tanpa memiliki karya pelukis A.A. Gede Sobrat. Sebagaimana penuturan Suteja Neka, pemilik Museum Neka. Ia mengatakan bahwa untuk mendapatkan karya A.A. Gede Sobrat, kegigihan sangat diuji. Berkali-kali Neka berusaha untuk mengoleksi karyanya, tetapi selalu dikatakan bahwa lukisannya tidak selesai dan sudah ada yang memesan. Pada saat pameran lukisan di Hotel Bali Beach, Neka dan istrinya datang. Mereka mendengar sedang berlangsung pameran lukisan hasil karya pelukis-pelukis Padang Tegal. Ternyata lukisan yang diminati Neka dipamerkan di sana. Oleh karena tempat pameran di hotel bertaraf internasional, maka harga-harga lukisannya pun cukup mahal. Biasanya mereka yang berani dan mampu membeli lukisan di dalam pameran seperti itu adalah turis manca- negara. Walaupun demikian, Nekka tidak membuang kesempatan, lukisan yang disenangi langsung dibeli. Beberapa hari kemudian A.A. Gede Sobrat mendengar berita bahwa Nekka sebagai pembeli lukisannya sehingga heran. Mulai saat itu A.A. Gede Sobrat percaya bahwa Nekka betul-betul berniat mengoleksi karyanya, di antaranya yang berjudul "Tari Tambulilingan" (1970).

Faktor ekonomi (pemasaran) merupakan salah satu keberhasilan meskipun tidak merupakan unsur yang mutlak. Namun, kecenderungan suatu karya lukis memperoleh yang baik kalau karya tersebut memiliki bobot atau 
nilai seni yang tinggi. Sebalikny,a apabila nilai kualitas ini dibaikan, maka sebuah karya pada suatu saat akan kehilangan peminat dan tidak memiliki pasaran. Karya Sobrat yang telah memiliki nama, menjadi incaran para konsumennya. Sobrat menjual lukisannya ke luar rumah, seperti ke Art shop. Sobrat menyadari bahwa menjajakan karyanya ke luar rumah, di samping harga lukisan akan jatuh juga martabat dan gengsi sebagai pelukis akan sulit diangkat apabila jatuh ke Art shop atau ke sistem ijon. Kebanggaan Sobrat atau pelukis lainnya kalau lukisannya terjual di pameran atau pembeli dan datang ke rumahnya. Oleh karena itu, karya-karya A.A. Gede Sobrat jarang kita jumpai dalam Art shop kalaupun ada diperoleh dari tangan ketiga. Selain itu, bagi A.A. Gede Sobrat ekonomi memberikan sesuatu yang sangat penting dalam perjalanan, perkembangan dan dalam proses berkreativitas. Oleh karena proses ekonomi ikut menentukan tumbuh dan berkembangnya proses berkarya. Di samping itu, dalam berkarya diperlukan modal yang cukup besar sehingga pelukis A.A. Gede Sobrat akan menemukan kesulitan apa bila tidak bisa mengembalikan modal tersebut dari hasil penjualan karyanya. Dengan terjualnya karya-karya A.A. Gede Sobrat, maka ikut menentukan tumbuhnya gagasan baru, di samping rangsangan untuk berkarya yang lebih kreatif. Dalam proses berkarya perlu diingat bahwa ekonomi yang mengimbangi perjalanan proses melukis, arus dibedakan, yakni pada saat lukisan diciptakan dengan saat lukisan berbicara sebagai benda komersial. Pada saat Sobrat berkarya atau menuangkan idenya dalam bidang kanvas, terlepas dari bidang ekonomi yakni, bertujuan agar profesinya berkembang di kemudian hari. Oleh karena itu Sobrat mempunyai pandangan bahwa dalam menciptakan karya seni kualitas atau mutu harus diutamakan karena hanya lukisan yang berkualitas akan nilai ekonomis yang dapat menghasilkan uang. Uang dapat dipergunakan memenuhi kebutuhan sehari-hari untuk menopang kehidupan keluarga, di samping dapat mengembangkan kreativitas dalam berkarya.

\section{Fungsi Pendidikan}

Fungsi pendidikan dapat menjamgkau beberapa hal, seperti: keterampilan, kreativitas, emosionalitas, dan sensibilitas. Misalnya, melatih diri melakukan seni, misalnya seni lukis, seseorang dapat meningkatkan ketrampilan tangannya dan ketajaman penglihatannya. Latihan itu juga dapat memperbesar daya khayalnya sehingga menjadi lebih kreatif.

Proses belajar melalui pendidikan pada umumnya dibedakan antara pendidikan dalam sekolah (formal) dan pendidikan luar sekolah (non formal). Walter Spies dan R Bonnet yang datang ke Bali, secara tidak disadari, telah memberikan pendidikan nonformal kepada pelukis-pelukis Pitha Maha yang ada di Ubud. Dalam pembelajaran tersebut Walter Spies dan R. Bonnet memberikan pendidikan konsep-konsep baru dalam bidang melukis. Ia memberikan kebebasan kepada pelukis Ubud untuk berkreasi, 
sehingga muncullah corak baru dalam bidang seni lukis yang diberi nama seni lukis Bali Modern. Dalam hal ini A.A. Gede Sobrat adalah salah satu muridnya. Dia mendapat pendidikan seni lukis dari kedua seniman asing tersebut. Dengan demikian, maka tidak dapat dipungkiri bahwa A.A. Gede Sobrat mendapat pendidikan nonformal dari lingkungan Ubud, yaitu dari guru Walter Spies dan R. Bonnet. Sehingga proses belajarnya disebutkan dengan proses akulturasi, yaitu proses sosial yang lamban. Sobrat mendapat pendidikan dari Bonnet dan Walter Spies, kemudian diteruskan oleh Sobrat kepada generasi berikutnya sehingga pendidikan tersebut bisa berlanjut.

Disamping fungsi seni tersebut di atas, Sobrat juga memberikan pendidikan kepada generasi berikutnya. Dalam proses ini sobrat memberikan pendidikan secara langsung dan tidak langsung. Pemanfaatan fungsi pendidikan secara langsung dapat dilihat dari banyaknya murid yang datang untuk belajar melukis di studio Sobrat. Salah satu muridnya yang pernah belajar di sana adalah A.A. Rai Konta, Dewa Made Pastika, Dewa Nyoman Leper, A.A.Gede Raka Puja, dan Dewa Putu Sugi dari Pengosekan. Dalam pembelajaran ini cara/gaya A.A. Gede Sobrat tidak jauh berbeda dengan gurunya Spies dan R. Bonnet dalam memberikan pelajarannya. Anak didiknya diberi kebebasan dalam aktivitas. Dengan diberikan kebebasan dalam berkarya diharapkan tumbuh beberapa hal, seperti keterampilan, kreativitas, emosional, dan sensibilitas. Dengan melatih diri dalam melukis peserta didik diharapkan dapat meningkatkan keterampilan tangan dan ketajaman penglihatannya (wawancara dengan A.A. Gede Raka Puja di rumahnya, Juli 20-2006).

\section{SIMPULAN}

Dari uraian sebelumnya mencerminkan bahwa A.A. Gede Sobrat memiliki beberapa keunggulan dan kelebihan seperti: teknik, anatomi, goresan, dan lain-lainnya yang tidak dimiliki oleh pelukis lainnya. Begitu pesatnya karya dari Anak Agung Gede Sobrat sehingga lukisannya menjadi mengglobal, dengan kata lain lukisan bukan saja tersimpan pada museummuseum yang ada di Bali, tetapi sudah merambah pada tingkat nasional bahkan internasional.

DAFTAR RUJUKAN

Anonim. 2004. Pedoman Penulisan Usulan Penelitian, Tesis, dan Disertasi. Denpasar: Program Pascasarjana Universitas Udayana.

Bastomi, Suwaji. 1992. Wawasan Seni. Semarang: IKIP Semarang Press.

Couteu, Jean. 2003. "Wacana Seni Rupa Bali Modern”, dalam Paradigma dan Pasar Yogyakarta: Yayasan Seni Cemeti.

Djelantik , A.A. M. 2004. Estetika. Sebuah Pengantar. Bandung: Masyarakat Seni Pertunjukan Indonesia. 
Gie The Liang. 1983. Garis Besar ( Filsafat Keindahan ). Yogyakarta: Super Sukses

Gie, The Liang. 1996. Filsafat Seni, Yogyakarta: Pustaka Belajar Ilmu Berguna (PUBIB). Yogyakarta.

Haviland, William A. 1988. Antropologi Jilid I dan II. (Terjemahan R.G. Sukarjito).

Jakarta : Erlangga.

.1996 Propil Seniman Gianyar. Gianyar: Diterbitkan Humas Kabupaten Daerah. Tingkat II Gianyar

.Kamus Besar Bahasa Indonsia. Jakarta:Departemen Pendidikan dan Kebudayaan Republik Indonesia.

Kartika, Sony Dharsono. 20004. Seni Rupa Modern, Bandung: Penerbit Rekayasa Sains Kondra, I Wayan. 2004. "Estetika Seni Lukis Ekspresionis Affandi”, (tesis) Program Pasca Sarjana Universitas Udayana Denpsar.

Koentjaraninggrat. 1990. Pengantar Ilmu Antropologi, Jakarta: Rineka Cipta.

Murdana I Ketut. 2001. Nilai-nilai Estetik Seni Lukis Bali Modern. Tesis Institut Teknologi Bandung.

\section{Nara Sumber:}

A.A.Anom Sobrat, Padang Tegal Tengah, Ubud

A.A. Gede Raka Puja, Padang Tegal Tengah, Ubud 